\title{
Academic Words in the English Research Article Abstracts: the Coverage and Frequency
}

\author{
Fransiskus Jemadi \\ Universitas Katolik Indonesia Santu Paulus Ruteng, \\ ikinjemadi@gmail.com \\ Fatmawati \\ Universitas Katolik Indonesia Santu Paulus Ruteng, \\ watti_f@yahoo.co.i \\ Priska Filomena Iku \\ Universitas Katolik Indonesia Santu Paulus Ruteng \\ priskafilomena90@gmail.com
}

\begin{abstract}
The present study aimed at exploring the abstracts of research articles written by non-native English researchers to uncover the specific characteristics of academic vocabulary employed in the English research articles abstracts.It focuses on frequency and coverage distribution of the words from the Academic Word List (Coxhead, 2000) in the abstracts of research articles. The source of data for this corpus study was gathered from 97 abstracts written by the EFL researchers and published by the Journal Pendidikan dan Kebudayaan Missio at STKIP St. Paulus Ruteng from 2015 until 2018. The results of this study revealed that the coverage of $\mathrm{K} 1$, the first most frequent 1000 English words, is the most dominant lexical items applied by the researchers. It covered $71.33 \%$ of the texts. The representation of lexical items that belong to $\mathrm{K} 2$, the second most frequent 1000 English words, covered 5.44\% of all the words used by the writers in their abstracts. Moreover, the presence of Academic Word List, which refers to a list of 570 word families that are commonly found in academic texts and Off-list, which refers to the words that do not belong to $\mathrm{K} 1$ or $\mathrm{K} 2$ because it is related to certain field, has slight difference over all of the texts where the former covers $11.95 \%$ and the later covers $11.26 \%$. As far as the findings of the present study are concerned, the room for some improvements on academic words applied in the abstracts need to pay attention.
\end{abstract}

ARTICLE HISTORY

Received 25 July 2019 Accepted 21 October 2019

\section{KEYWORDS}

Abstracts; academic words

\section{Introduction}

The selection of words and language use is attributed to writing in the academic context (Finoza, 2009). The use of academic vocabulary as one of the characters of academic writing is crucial to support the quality of scientific work. The high frequency of higher level of English vocabulary in writing academic text contributes 
to the appropriate use of language and style (Choo, et al, 2017), which then supports reading comprehension (Stahl \& Fairbanks, 1986, cited in Zwiers 2008).).In line with this, Mukoroli (2011) in Choo, et al. (2017: 57) asserts that"learners with higher academic vocabulary development are better at tolerating a small proportion of unknown words in a text without disruption of comprehension and can even infer the meaning of those words from rich contexts". On the other hand, when students lack vocabulary knowledge, they will have low ability for reading comprehension.

Vocabulary is considered to be demanding for L2 learners when they are encountered with reading and writing academic discourse (Shaw, 1991; Fadda, 2012; Chanasattru, \& Tangkiengsirisin, 2017). In Indonesia, where English is taught as a foreign language, English is introduced since primary school to university. However, students' main problem when dealing with reading and writing task is dominated by a lack of vocabulary. This condition is in line with the condition in Thailand where insufficient vocabulary knowledge is one of the major difficulties that Thai students face when reading even though they have been studying English for more than twelve years (Aegpongpaow, 2008 in Chanasattru, \& Tangkiengsirisin, 2017).

Considering the significance of academic vocabulary in a scientific context, the teaching of vocabulary needs attention in teaching foreign languages, especially English. In fact, academic vocabulary has less attention in the teaching of English (Mercer dan Zimmerman, 2015). Determining which vocabulary to include in the teaching materials is an arduous decision. This assumption echoes Vongpumivitch, Huang \& Chang's, (2009) idea on the teaching of vocabulary, stating that "deciding which words are worth teaching has not been a simple matter".

Academic Word List (AWL) created by Coxhead (2000), which covers academic words of four disciplines: law, art, commerce, and science is practical for the teaching of English vocabulary. "Word lists help learners and teachers orient themselves in the sea of English language vocabulary as it presents the most frequently used and significant vocabulary in the language or a specific genre or scientific area" (Palinkašević, 2017).Regarding this, Zwier (2009) asserts that "rich vocabulary instruction and practice that target vocabulary from the AWL provides opportunities for students to improve their language proficiency and their ability to decode and process vocabulary". In addition, Joseph Picot (2017) emphasizes the importance of AWL, "Word lists provide an opportunity for teachers to understand the depth and breadth of the target vocabulary."To conclude, the AWL can be considered as a guide for both teachers and students about the vocabulary that is worth studying.

The research on the use of academic vocabulary in scientific context has attracted the attention of other researchers, for example, Coxhead and Nation (2001) report that AWL words cover around $8.5-10 \%$ of the words used in academic texts. Cobb and Horst (2004) show that knowledge of AWL words and also knowledge of words in the western general service list (GSL) (1953) is needed in understanding 
academic texts in English. Other research studies have shown the important role of AWL in certain academic texts as in medical research (Chen \& Ge, 2007), and anatomy and applied linguistics(Chung \& Nation, 2003).

The present study concerns the frequency of academic vocabulary and its coverage in the abstracts of research articles written by non-native English speaker researchers in Journal Pendidikan dan Kebudayaan Missio. The abstract part was chosen because it represents the content of the whole article so that the selection of diction related to scientific words is significant to note. This current study seeks to answer the following questions:

1. To what extent is the coverage of lexical items in abstracts written by EFL researchers in Journal Pendidikan dan Kebudayaan Missio?

2. How do the research abstracts in Journal Pendidikan dan Kebudayaan Missio provide AWL in terms of frequency?

\section{Methodology}

The present study aimed at exploring the abstracts of research articles to uncover the specific characteristics of academic vocabulary employed by the researchers whose status of English is as a foreign language. It focused on frequency, coverage, and distribution of the words from the Academic Word List in the abstracts of research articles. The source of data for this corpus study was gathered from 97 abstracts written by the EFL researchers and published in the Journal Pendidikan dan Kebudayaan Missio at STKIP St. Paulus Ruteng from 2015 until 2018. This journal publishes two editions annually, in which every edition is generally comprised of 10 to 16 articles. All of the research article abstracts are written both in English and in Bahasa Indonesia, and the data for the present study are taken from the English version of the abstracts.

The procedures applied by the researchers for the present study were as follows. First, the researchers downloaded all of the available articles published by the Journal Pendidikan dan KebudayaanMissio from 2015 to 2018 and extracted all the English abstracts on the computer and saved them as plain texts for further operation. The extraction process aimed to meet all the prerequisites that are required by the VocabProfiler for the data analysis such as any constructions and misspelling of words that were revised. All numbers and percentages were rewritten in words, and foreign abbreviations and punctuations were deleted. Having taken into account all of those points, all of the abstracts were put into VocabProfile to analyze the words into four categories based on their frequency which are 1) the most frequent 1000 English words (K1); 2) the second most frequent 1000 English words (K2); 3) academic words from the AWL; 4) off-list words.

\section{Result}


The present study sought to examine the coverage and frequency of Academic Words in the abstracts of research articles published by the Jurnal Pendidikan dan Kebudayaan Missio and written by the researchers who are non-native English speakers.

Table 1. Coverage of lexical items in the abstracts

\begin{tabular}{|c|c|c|c|c|c|}
\hline Year & $\begin{array}{l}\text { Word } \\
\text { List }\end{array}$ & families & Types & Tokens & $\%$ \\
\hline \multirow{4}{*}{2015} & $\mathrm{~K} 1$ & 346 & 486 & 2073 & 71.19 \\
\hline & $\mathrm{K} 2$ & 55 & 67 & 126 & 4.33 \\
\hline & AWL & 138 & 176 & 343 & 11.78 \\
\hline & Off-list & $?$ & 233 & 370 & 12.71 \\
\hline \multirow{4}{*}{2016} & K1 & 389 & 563 & 3234 & 69.56 \\
\hline & $\mathrm{K} 2$ & 93 & 126 & 271 & 5.83 \\
\hline & AWL & 188 & 274 & 602 & 12.95 \\
\hline & Off-list & $?$ & 314 & 542 & 11.66 \\
\hline \multirow{4}{*}{2017} & K1 & 317 & 452 & 2287 & 72.93 \\
\hline & $\mathrm{K} 2$ & 67 & 92 & 67 & 5.8 \\
\hline & AWL & 144 & 184 & 365 & 11.64 \\
\hline & Off-list & $?$ & 169 & 302 & 9.63 \\
\hline \multirow{4}{*}{2018} & K1 & 386 & 577 & 3418 & 71.67 \\
\hline & $\mathrm{K} 2$ & 75 & 108 & 277 & 5.81 \\
\hline & $\overline{A W L}$ & 163 & 229 & 546 & 11.45 \\
\hline & Off-list & $?$ & 265 & 528 & 11.07 \\
\hline
\end{tabular}

Table 1: The coverage of lexical items in the abstracts

The coverage of lexical items found in the abstracts, as revealed from table 1, presents different coverage of lexical items published between 2015 and 2018. The coverage of $\mathrm{K} 1$ is the most dominant lexical items applied by the writers with a mean of $71.33 \%$ of texts. The representation of lexical items that belong to the K2 word list covers $5.44 \%$ of all the words used by the writers in their abstracts. Moreover, the presence of Academic Word List and Off-list has a slight difference over all of the texts written by the writers in their abstracts where the former covers $11.95 \%$, and the later covers $11.26 \%$. 
Table 2. Frequency analysis of the AWL in the abstracts.

\begin{tabular}{llllll}
\hline Year & $\begin{array}{l}\text { Word } \\
\text { List }\end{array}$ & Families & types & tokens & $\%$ \\
\hline 2015 & AWL & 138 & 176 & 343 & 11.78 \\
\hline 2016 & AWL & 188 & 274 & 602 & 12.95 \\
\hline 2017 & AWL & 144 & 184 & 365 & 11.64 \\
\hline 2018 & AWL & 163 & 229 & 546 & 11.45 \\
\hline
\end{tabular}

Based on table 2 above, the mean of AWL applied by the writers on their abstracts is $11.95 \%$. The most frequent AWL used by the writers is the abstracts published in 2016 with a percentage of $12.95 \%$, while the other three years of publication, the frequency of AWL is slightly similar. The frequency of AWL in the abstracts published in 2015 is $11.78 \%$, in 2017 it is $11.64 \%$, and in 2018 is 11.45.Based on the results of data revealed in table 2 , it can be inferred that the frequency of AWL in the abstracts of research articles published in 2016 was higher compared to other years of publication

\section{Discussion and Conclusion}

This study sheds light on this field of corpus study in order to broaden the understanding of academic vocabulary, especially in terms of its use in English academic context by the speakers of other languages. This study has revealed a list of 15351-word forms that are applied by the other speakers of English in their published research abstracts in the Journal Pendidikan dan Kebudayaan Missio. The result of this study revealed that the first most frequent 1000 English words (K1) of Coxhead (2000) was the most dominant word forms found in the published research abstracts in which it covered $71.33 \%$. The second was followed by the AWL which covered $11.95 \%$. The third was the off-list words, which covered $11.26 \%$, and the last was the second most frequent 1000 English words (K2), which covered 5.44\% overall of the published abstracts studied.

Besides the information supplied above, $11.95 \%$ of AWL found in the present study is even higher compared to Coxhead's (2000) Academic Word List. The result of her study revealed that the presence of AWL covered $10 \%$ in the corpus of four disciplines (Arts, Commerce, Law, and Science). Moreover, the study conducted by Martinez, Beck, and Panza (2009) found that the AWL in the AgroCorpus research articles covered only $9.06 \%$ out of the 23,682 types. This finding seemed to confirm the finding of AWL words in applied linguistics articles that have been previously researched by Vongpumivitch, Huang, and Chang (2008). They investigated the frequency of the Academic Word List (AWL) and non-AWL content words in 200 research articles of applied linguistics research papers. They discovered that the AWL 
covered $11.17 \%$ of the entire corpus and comprised of 175 AWL and 128 non-AWL words.

Another interesting finding of the present study was even though there was $11.95 \%$ of AWL found in the abstracts written by the researchers of speakers of other languages, most of those AWL belonged to the first three sub-lists of Coxhead (2000). In other words, the higher the level of Academic Word List, the lower the presence of AWL applied by the researchers in their abstracts. This finding seemed to be in line with the finding claimed by Vongpumivitch, Huang, and Chang (2008) whose study revealed that that identified AWL in the corpus belonged to the category of Coxhead's first and second sublists words.

Gardner \& Davies in Palinkašević (2017) states that Word lists are beneficial to both learners and teachers because they serve them with the most frequently used and significant vocabulary in the specific genre or scientific area. They could be assisting means for the teachers and the students to establish their vocabulary learning objectives, assess their vocabulary knowledge and growth, analyze text difficulty and richness, determine the vocabulary components of academic curricula, create and modify reading materials, and design vocabulary learning tools. Moreover, Dang, Coxhead and Webb (2017) argued that AcademicWord List helps L2 learners improve their comprehension of academic written texts and academic achievement.Henceforth, with respect to the finding of the present study, it would have some pedagogical implications for the teachers and the students that explicit teaching AWL to the students is required to expand the vocabulary knowledge of the students and the use of vocabulary profiling tools could serve as a filter for academic lexis. In addition, the corpus of the present study was taken from the abstracts section only and was still relatively small compared to the Coxhead's academic corpus which comprised 3.5 million running words. Thus, future researchers need to take into account the size of their corpus and not only limited to the particular section of the research articles. 


\section{References}

Al-Ma'ruf, Ali Imron dan Farida Nugrahani. 2008. Metode Penulisan Karya Ilmiah Panduan Bagi Mahasiswa, ilmuwan, dan eksekutif. Yogyakarta: Pilar Media

Al Fadda, Hind. 2012. Difficulties in Academic Writing: From the Perspective of King Saud University Postgraduate Students. English Language Teaching Vol. 5, No. 3; March 2012. Accessed 11July 2019, from www.ccsenet.org/elt

Byrne, S. 2016. An Examination of Successful Language Use at B1, B2, an C1 Level in UCLanESB Speaking Tests in Accordance with the Common European Framework of References for languages. Dissertation. University of Central Lancashire

Chanasattru, S., \& Tangkiengsirisin, S. 2017. The Word List Distribution in Social Science Research Articles. Arab World English Journal, 8 (4). DOI: https://dx.doi.org/10.24093/awej/vol8no4.28

Chen, Q. \& Ge G.C. 2007. A Corpus-Based Lexical Study on Frequency and distribution of Coxhead's AWL Word Families in Medical Research Articles. English for Specific Purposes 26 (4), 502-514, 2017.

Choo, Lee Bee, et al.2017. The Significance of the Academic Word List among ESL Tertiary Students in a Malaysian Public University. The Southeast Asian Journal of English Language Studies - Vol 23(4): 56 - 65

Chung, T. M. \& Nation P. 2003. Technical vocabulary in specialised texts. Reading in a Foreign Language Volume 15, No. 2, October 2003

Cobb, T. Range For Texts V.3 [Computer Program]. Accessed 15 Sept 2015 at https://www.lextutor.ca/cgi-bin/range/texts/index.p

Cobb, T. dan Horst, M. 2004. Vocabulary in a second language. Amsterdam: Benjamins Publishing.

Coxhead, A. 2000. A New Academic Word List. TESOL quarterly, 34(2), 213-238.

Coxhead, Averil, and Paul Nation. 2001. The specialised vocabulary of English for academic purposes. Research perspectives on English for academic purposes (2001): 252-267. 
Dang, T. N. Y., Coxhead, A., \& Webb, S. 2017. The Academic Spoken Word List. Language Learning, 67(4), 959-997.

Finoza, Lamudin. 2007. Komposisi Bahasa Indonesia. Jakarta: Diksi Insan Mulya.

Gerrot, L. and Wignell, P. 1995. Making Sense of Functional Grammar. Sydney: Gerd Stabler.

Martínez, I. A., Beck, S. C., \& Panza, C. B. 2009. Academic vocabulary in agriculture research articles: A corpus-based study. English for specific purposes, 28(3), 183-198.

Mercer, N.B dan Zimmerman, C.B. 2015. Fostering Academic Vocabulary Use in Writing. The CATESOL Journal 27.1. 2015

Palinkašević, R. 2017. Specialized Word Lists-Survey of the Literature-Research Perspective. Research in Pedagogy, 7(2), 221-238.

Joseph Picot, C. 2017. Using Academic Word Lists to Support disciplinary Literacy Development. The Reading Teacher, 71 (2), 215-220.

Saragih, Amrin. 1999. "Penulisan Artikel Ilmiah. Makalah Disajikan dalam Pelatihan Penulisan Artikel Ilmiah di Medan”. FPBS IKIP Medan, 20-21 April.

Shaw, P. 1991. Science Research Students' Composing Processes. English for specific purposes 10,189-206

Suganda, Tarkus. 2014. "Teknik Menulis Artikel Ilmiah dari Laporan Penelitian Skripsi, Tesis dan Disertasi”. Https://www.researchgate.net/publication/262561789 TEKNIK_MENULIS_ARTIKEL_ILMIAH_DARI_LAPORAN_PENELITIA N_SKRIPSI_TESIS_DAN_DISERTASI. Accessed 3 October 2018www.uefap.com/writing/feature/featfram.htm

Vongpumivitch, V., Huang, J. Y., \& Chang, Y. C. 2009. Frequency analysis of the words in the Academic Word List (AWL) and non-AWL content words in applied linguistics research papers. English for Specific Purposes, 28(1), 33-41.

Zwiers, J. 2008. Building Academic Language. Newark International Reading Association. 